Note

\title{
ARCHAEOLOGICAL MATERIAL FOR THE STUDY OF CROP EVOLUTION
}

\author{
Fábio de Oliveira Freitas ${ }^{1 *}$; Paulo Sodero Martins ${ }^{2}$ \\ ${ }^{l}$ Embrapa Recursos Genéticos e Biotecnologia - PqEB, s/no - Av. W5 Norte, Final - 70770-900, Brasília - \\ DF, Brasil. \\ In Memorian \\ *Corresponding author <fabiof@cenargen.embrapa.br>
}

\begin{abstract}
This research studies archaeological samples of maize (Zea mays mays) and cassava (Manihot esculenta), from Januaria, MG, Brazil, for samples between 1010 (for the oldest sample) and 570 years (for the most recent) as estimated through radiocarbon dating. Maize cobs were morphologically analysed by using length, basal and apical diameters, largest diameter, number of rows, number of grains per row, and number of grains per row per length parameters. The maize cob length presented increases through time, allowing an increase on the number of seed per cob, but the size of seeds did not vary significantly. Starch present in the reserve organs of the maize and cassava were analysed morphologically through Scanning Electron Microscopy, and compared to indigenous and modern samples, aiming to estimate the diversity of the material and, for the cassava, to assure that samples were truely Manihot sp. The starch of the maize and cassava reserve organs was in excellent state of conservation and the morphology of the starch grains allowed the separation of maize varieties. More than one variety of maize was found on a same period of time, suggesting that the old indigenous people of the area planted different varieties of maize simultaneously and these varieties changed through the studied period of time. Finally archaeological starch grains of maize presented more diverse standards than modern grains.
\end{abstract}

Key words: Zea mays, Manihot esculenta, archaeology, indigenous, starch

\section{MATERIAL ARQUEOLÓGICO PARA O ESTUDO DE EVOLUÇÃO DE PLANTAS CULTIVADAS}

\begin{abstract}
RESUMO: Amostras arqueológicas de milho (Zea mays mays) e mandioca (Manihot esculenta), oriundas da região de Januária, Minas Gerais, Brasil, com idades estimadas entre 1010 anos para a amostra mais antiga, até 570 anos para as mais novas, foram estudadas morfologicamente. No caso do milho, tomaram-se medidas de comprimento da espiga, diâmetro basal, diâmetro apical, diâmetro maior, número de fileiras, número de grãos por fileiras e número de grãos por fileiras por comprimento. O tamanho da espiga aumentou com o tempo, permitindo aumento da quantidade de sementes, mas sem que estas sementes sofressem uma variação significativa em seu tamanho. Amostras de grãos de amido das sementes de milho e do tubérculo de mandioca foram estudados por meio de microscopia eletrônica de varredura e comparadas com amostras de raças indígenas e etnovariedades, para estimar a diversidade deste material e, no caso do tubérculo, para certificação que se tratava realmente de mandioca e não uma outra espécie. O amido dos órgãos de reserva do milho e mandioca encontram-se em excelente estado de conservação e, através da morfologia dos grãos de amido foram separadas raças ou variedades de milho. Constatou-se a presença de mais de uma raça de milho em um mesmo período de tempo e estas raças foram variando ao longo do período analisado (de 1010 a 570 anos atrás). A variabilidade dos grãos de amido das amostras arqueológicas de milho se apresentou maior do que as amostras atuais utilizadas.
\end{abstract}

Palavras-chave: Zea mays, Manihot esculenta, arqueologia, indígena, amido

\section{INTRODUCTION}

The study of the domestication of plants practically began in 1886 with the pioneer work of Alphonse de Candolle (Candolle, 1959), and increased with the development of the methodology of differential fitogeography of Vavilov (1926), quoted by Harlan (1975), Today it is experiencing great expansion as a result of joint analyses methodologies (Harlan, 1975). These methodolo- gies deal with evidences obtained from the plants themselves, including the live material (experimental taxonomy, ecology, genetic systems, variation patterns, genetic reconstruction) and archeological material (archaebotanic, palinology, paleobotanic), the activity of contemporary men (language, oral tradition, techniques, nutrition) and the past (history, art, archeology, physical anthropology) and other sources (geology, hydrology etc.) (Harlan \& De Wett, 1973). 
The studies on the origin of agriculture and, consequently, on the domestication of plants and animals, implicate in different aspects. Four fundamental questions have been formulated for decades: Where did agriculture begin? When did it happen? Which processes were used? And why did men stop being a collector and a hunter, and start producing its food systematically?

During the long evolutionary history of human race, man has survived gathering plants, hunting and fishing, but only about 10 to 15 thousand years ago he started the development of agriculture and the domestication of animals. Research, as expected, has concentrated its attention to ancient civilization areas, where there is a large amount of archeological evidences. In tropical areas, like Brazil, these studies are still restricted to only a few groups of work. Nevertheless, archeological work in Brazil (Prous, 1986; 1991; Roosevelt, 1996) has evidenced the existence of rupestre art indicating vegetal gather activity and agriculture, and what is extremely important, have found vegetal archeological material in large amounts and in excellent preservation conditions, allowing taxonomic analysis of the material with the possibility of establishing relations to races still cultivated nowadays by indigenous people.

In this context, the recent discoveries of cultivated materials in several archeological sites of Brazil, mainly in the north of the Minas Gerais State, allow to know a little more about the agriculture, as it was performed during the pre-colonial Brazil, bounding archeological, historical and contemporary data. The analysis of these archeological materials contributes effectively, not only to classify them taxonomically, but also to understand the evolutionary dynamics of the plant domestication process in tropical areas.

Complementing this context, the analysis of the process of handling plants, traditionally cultivated by indigenous Brazilian people, is offering important information that has allowed to formulate hypothesis on the evolutionary dynamics of these plants, and the elaboration of models on the evolution of crops in the lowlands of South America (Martins, 1994).

\section{MATERIAL AND METHODS}

The material used was divided in two parts: one made up by archeological material and the other by accessing the Germplasma Genebank of CNPMS, EMBRAPA. This material was obtained through archeological excavations of late 1970s, in old rock shelters used by pre-historical man in the Vale do Peruaçu, in the region of Januária-MG $\left(15^{\circ} 29^{\prime} 27^{\prime \prime S}\right.$, $44^{\circ} 21^{\prime} 32^{\prime}$ W), North of the State of Minas Gerais (Figure 1), by the co-workers of Dr. André Prous, the "Museu de História Natural de Minas Gerais - UFMG". Throughout this valley, a high amount of vestiges that man was in that region since at least 10,000 years ago can be found, a fact revealed first by the enormous quantity of rupestre paintings present in many archeological sites of the region, and later the mate- rials found in escavations, like tools made of stone, ceramic pots, human skeletons and vegetal vestiges.

The vegetal material is made up, in its major part of maize cobs (Zea mays mays), some of them complete with seeds and husk, but most of them were cob without seeds. Also present were a great amount of maize seeds, besides coal fragments, "coconut" Guariroba (Syagrus oleracea); manioc (Manihot esculenta); cotton seeds (Gossypium sp.); peanut (arachis sp.); passion fruit (Passiflora sp.); "cabaça" (Legenaria Vulgans); "urucum" (Bixa orellana), among others. All this material is characterized by its excellent state of preservation.

This vegetal material was buried and arranged in an underground storage "silo", made up of an interlaced palm fiber basket in which the vegetal material was deposited and then covered with the same interlaced fiber, put inside a hole dug on the ground, and over the "silo", soil and fire ash was added, diminishing insect attack.

The analyzed material came from 10 "silos" of 2 archeological sites of the Vale do Peruaçu: 1. Boquete (most part of the material) and 2. Lapa da Hora. In this first period of research, the analyses were concentrated over samples of maize (Zea mays mays) and manioc (Manihot esculenta) samples.

For comparison, 21 accesses of indigenous maize seeds and of ancient commercial varieties were obtained from the Germplasma Genebank of "EMBRAPA - Milho e Sorgo", in Sete Lagoas, Minas Gerais, Brazil. The date of the archeological material was estimated using the method-

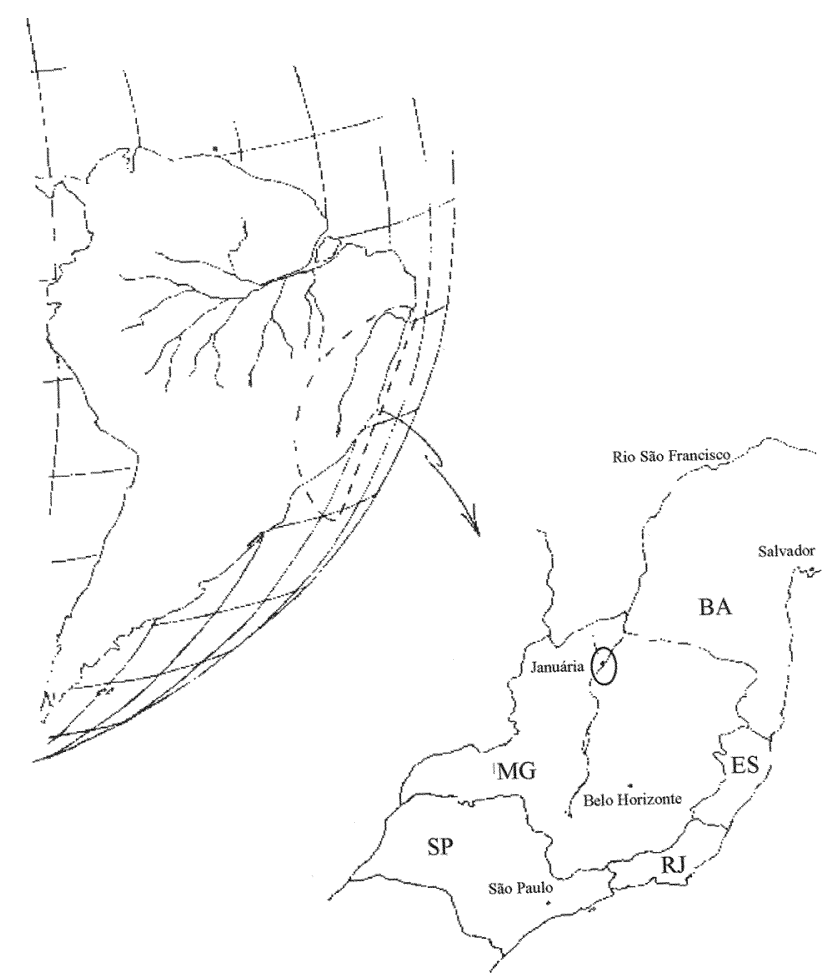

Figure 1 - Map with the localization of the region where the samples were found, in caves and shelters of Vale do Peruaçu, Januária, Minas Gerais, Brazil. 
ology of radiocarbon dating, by spectrometry of liquid scintillation with benzene (Pessenda \& Camargo, 1991).

For the time dating, samples of "coconut" (Syagrus oleracea) fragments and charcoal were found inside the "silos" in such a way that the samples of maize and manioc could be preserved, were used. Related to morphology, the following measurements were made on maize cobs (female inflorescence): major, basis and top cob diameters; cob length; number of seed rows; number of seeds per row; and relation between the length of the cob and the number of seeds per row.

Data were then analyzed statistically (Steel \& Torrie, 1960; Sneath et al., 1973; Caanings \& Hoppensteadt, 1982), trying, throughout the external morphology, to compare different "silos" to know if the maize belonged to an unique race or to more than one, and if there is any difference in the material found inside the "silos", among the "silos", among the archeological sites, and along the past and present time.

Starch, present in the storage organs of the plants is, after cellulose, the most abundant component processed by the vegetal cell (Swinkels, 1985). The starch morphology is specific for each species (Hall \& Sayre, 1970; Gallant \& Bouchet, 1978; Galliard, 1987; Freitas, 1996), a fact that is used to identify species when they cannot be clearly identified by external morphology (Ugent et al., 1986), as it is the case in the present study, with the fragments of the archeological tubercle, which could be of a manioc or any other species. The starch is used to compare present species with archeological materials to verify if some evolution in the structure of the starch through time could be detected and, in the case of maize, if it could be used to distinguish different races of that species (Evans, 1941; Boyer et al., 1976; Gallant \& Bouchet, 1978; Freitas. 1996).

For that purpose, a small quantity of starch from the storage tissue of the maize seed and of the tubercle were used, which were analyzed in an scanning electron microscope - SEM, model Zeiss DSM 940A, using 5kV. A small sample of starch was collected and placed on a carbon adhesive tape pair-face, prepared directly on the microscope blade (stub), and covered with gold for 120 seconds. From each sample of the material 300 grains of starch were measured, in a total of 6300 grains of starch measured from the accesses of the germplasma genebank, and 4800 grains from the archeological material. From each grain of starch two measurements were taken, the longest length and the longest orthogonal in relation to the first measurement. The relation between these two measurements was also calculated to have a pattern of the form of the grains, since some grains were well rounded and others longer or elliptical.

A statistical analyzes was made for the interpretation of the data, using the analyses of variance, and later, the test of Turkey, to compare the averages of starch grains (Steel \& Torrie, 1960).

\section{RESULTS AND DISCUSSION}

\section{Age of the material}

The determined age of corn ranged from $1010 \pm 80$ years for the oldest sample, until $570 \pm 60$ years for the most recent one, with other samples with intermediary ages. The manioc tubercle is $860 \pm 60$ years old. These samples of cultivated crops are among the oldest dated in Brazil in a definitive way, indicating the importance of the material and of the archeological sites.

On the other hand, all this material belongs to the pre-colonial period, which has no documented history in written records, the dating remaining as a researcher duty in order to have the history of the native population, better elucidated. These dates indicate that the population of this region was already cultivating maize for at least 1000 years ago, and continued this process during the 500 following years. However, there are evidences of the use of these shelters for at least 10,000 years, and the number of "silos" dated is only a small sample of what exists. There is a great chance that the maize could have been introduced to this region before 1000 years, mainly because of the diversity of races that already existed in that period of time, determined by the analyzes of the starch of seeds from this "silo", and also from the great morphological difference existing among the different samples of maize cobs, as well the color and morphology of the seeds.

Attention must be paid to the fact of the existence of untouched maize ears belonging to the same "silo". These ears have different forms, and distinct aleuronic color, some orange and others purple-brown, with no segregation of color in a same ear, i.e., apparently there are different "pure" races in one "silo". A difference in color and form among them, without indication of segregation in a same maize ear, suggests that the inhabitants of that place owned more than one field of plantation, or they planted distinct races of maize in different periods, so that the crossing among them was not allowed, because if it happened, it would result in ears with seed segregation, i.e., with more than one color in the same ear. This fact suggests that the maize was already important in the culture of these people, and that they knew the maize reproductive habit, so that their contact with the maize must have happened before this specific time, as suggested by Prous (1986) and Bird e. al. (1991), who believe that the maize was already grown in that region before the year 4000, fact based upon the sedimentary time level in which some samples were found, still needing a more direct dating to confirm this fact.

Regarding the nature of the "silos", an alternative hypotheses is that they were, in fact, part of religious rituals and not objects to store for further consumption, mainly because the large amount of "silos" found, presented no signs that at any moment they have been used after been buried. An observation that reinforces this hypothesis is that part 
of this material seems to have been used before it was stored, is shown for one manioc fragment, which present signs that it has been grated. In addition, all fragments of Guariroba "coconut" indicates that they were broken for the possible use of their almonds, and only their broken barks were put in the "silo".

\section{Ear analyzes}

From all the analyzed data, the one that required more attention was the number of seed rows in the ear that, depending on the sample, varied from 6 to 18 rows, indicating the existence of a great diversity, even inside of an unique "silo", appearing since primitive race types, characterized by the presence of a few rows of seeds in the ear, until more elaborated races, with a higher number of rows, (Freitas, 1996). In addition, the comparison among the number of seeds per row and the number of seeds per row per length is interesting, because when these data are analysed together with the age of the material, it could be seen that there was a tendency of the number of seeds per row per length to be maintained constant along the time, whereas the number of seeds per row increased with the time. The increase of this relation and a certain stability in the other means that, in terms of evolution, the length of the maize ear was becoming higher with the time, allowing an increase in the quantity of seeds, but with no significant variation in the seeds size.

\section{Starch analyzes}

The first observed fact through the scanning electron microscope was the integrity of the starch grains, showing that these resist very well along the years they were buried and that they are an important object for study.

Sixteen archeological maize seeds from seven "silos" were analyzed and were compared to 21 accesses from the germplasma genebank, in which the archeological material presented a variability at least two times greater than the germplasm samples together, confirming the existence of a great diversity of races in the archeological material, due to several patterns found, as in relation to the morphology of the grains, as in the distribution in size classes. For a better description of these data and analyses see Freitas (1996).

All the analyzes with the archeological material presented a great diversity of races, in the same period of time. The characterization of these races is very important as a tool for the understanding of possible human/plants migration routes, or to know human contact areas among ancient prehistorical population. Knowing where and when some races appeared in Brazil and in South America, leads to a better idea of where given crops entered and spread along Brazil, and which were the races that were there developed.

In addition, the valorization and study of contemporary indigenous populations can allow to understand how people in the past handled their plants, and how these ways of handling contributes to the generation of new crop races, so that models on the evolutionary history of some kinds of species could be better formulated.

\section{ACKNOWLEDGEMENTS}

To Dr. André Prous and to the colleagues of the "Museu de Arqueologia de Belo Horizonte - UFMG", for the archeological material; to the Department of Genetics of USP/ESALQ, to CNPq for the support and to the natives of yesterday and of today, from which we have a lot to learn.

\section{REFERENCES}

BIRD, R.MCK.; DIAS JR., O.; CARVALHO, E.T. Subsídios para a arqueobotânica no Brasil: o milho antigo em cavernas de Minas Gerais, Brasil. Revista de Arqueologia, v.6, p.14-31, 1991.

BOYER, C.D.; SHANNON, J.C.; GARWOOD, D.L.; CREECH, R.G. Changes in starch granule size and amylose percentage during kernel development in several Zea mays L. genotypes. Cereal Chemistry, v.53, p. 327-337, 1976

CANDOLLE, A. Origin of cultivated plants. 2.ed. New York: Hafner, 1959

CANNINGS, C.; HOPPENSTEADT, F. An introduction to mathematical taxonomy. Cambridge: University Press, 1982.152 p.

EVANS, J.W. Microscopic examination of developing corn starch. Scientific Journal Series, Minnesota Agricultural Experiment Station, July, p.462-464, 1941.

FREITAS, F.O. Descrição e análise de material vegetal de sítios arqueológicos da região de Januária, Minas Gerais. Piracicaba: USP/ ESALQ, 1996. 83p. (Dissertação-Mestrado)

GALLIARD, T. Starch: properties and potencial. S.1.: Society of Chemical Industry, 1987. 185p.

GALLANT, D.J.; BOUCHET, B. Ultrastructure of maize granules: a review. Food Microstructure, v.5, p.141-155, 1978.

HALL, D.M.; SAYRE, J.G. A scanning electron-microscope study of starches: Part II: Cereal starches. Textile Research Journal, v.39, p. 256-266, 1970.

HARLAN, J.R. Crops and man. Madison: ASA, CSSA, 1975. 295p.

HARLAN, J.R.; DE WET, J.M.J. On the quality of evidence for origin and dispersal of cultivated plants. Current Antropology, v.14, p.51-55, 1973.

MARTINS, P.S. Biodiversity and agriculture: Patterns of domestication of Brazilian native plant species. Anais da Academia Brasileira de Ciências, v.66, p.219-224, 1994.

PESSENDA, L.C.R.; CAMARGO, P.B. Datação radiocarbônica de amostras de interesse arqueológico e geológico por espectrometria de cintilação líquida de baixo nível de radiações de fundo. Quimica Nova, v.14, p.98-103, 1991.

PROUS, A. L'archéologie au Brésil: 300 siécles d'occupation humaine. L'Anthropologie, v.90, p.257-306, 1986.

PROUS, A. Alimentação e "arte"rupestre: nota sobre alguns grafismos préhistóricos brasileiros. Revista de Arqueologia, v.6, p.1-15, 1991.

ROOSEVELT, A.C. Paleoindian cave dwellers in the Amazon: The peopling of the Americas. Nature, v.272, p.373-383, 1996.

ROSENTHAL, F.R.T.; BARBOSA, C.M.; MELlO, A.P.; SILVA, M.O. Amidos de mandioca: 1. Características dos grânulos de 11 variedades procedentes do Estado de Minas Gerais. Anais da Academia Brasileira de Ciências, v.44, p.55-60, 1972.

SNEATH, P.H.A.; SOKAL, R.R. Numerical taxonomy. New York: W.H. Freeman, 1973. 573p.

STEEL, R.G.D.; TORRIE, J.H. Principles and procedures of statistics. New York: McGraw-Hill Book, 1960.

SWINKELS, J.J.M. Composition and properties of commercial native starches. Starke, v.37, p.1-5, 1985.

UGENT, D.; POZORSKI, S; POZORSKI, T. Archaeological manioc (Manihot) from Coastal Peru. Economic Botany, v.40, p.78-102, 1986.

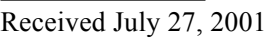

